\title{
ENVIRONMENTAL, SOCIAL AND GOVERNANCE DISCLOSURES ON FINANCIAL PERFORMANCE OF PUBLIC LISTED COMPANIES IN MALAYSIA
}

\author{
Saunah Zainon', Rina Fadhilah Ismail ${ }^{2}$, Sofwah Md. Nawi ${ }^{3}$, Roslina Mohamad \\ Shafi $^{4}$, Faridah Najuna Misman ${ }^{5}$ and Nor Balkish Zakaria ${ }^{6}$ \\ 1,3,4,5,6 Universiti Teknologi MARA Cawangan Johor, Malaysia \\ E-mail: sauna509@uitm.edu.my \\ ${ }^{2}$ Faculty of Accountancy, Universiti Teknologi MARA, Puncak Alam Campus, Selangor \\ E-mail: rinafadhilah@uitm.edu.my
}

\begin{abstract}
This study investigated the impact of environmental, social and governance (ESG) disclosures on financial performance as captured by firms' value of public listed companies (PLCs) in Malaysia due to the growing interest in ESG disclosure practices. The sample consisted of 114 PLCs in Malaysia selected from Datastream. All the selected companies had a complete ESG for 2019. Using the ESG score index, the mean score for each disclosure was computed. Both correlation and regression analyses were carried out to investigate possible links between ESG and accounting measures of financial performance as a proxy by the Weighted Average Cost of Capital (WACC). Based on a regression analysis, ESG was discovered to have a significant relationship with WACC. In addition, further analysis revealed that out of the three dimensions of ESG, social disclosure had a significant impact on financial performance compared to environmental and governance disclosure. This study provides empirical evidence concerning the dominant impact of social disclosure for firms' financial information. It also provides environmental and governance disclosures that are important for stakeholders. The results offer stakeholders more transparent and useful information on corporate social responsibility reporting which provides for a more visible reporting in order to gain trust from stakeholders.
\end{abstract}

Keywords: environmental, social, governance (ESG) disclosures, financial performance, weighted average cost of capital (WACC)

$\underline{\text { ARTICLE INFO }}$

Article History:

Received: 26 March 2020

Accepted: 27 August 2020

Published: 31 December 2020 


\section{INTRODUCTION}

The goal of environmental, social and governance (ESG) disclosure of information is to look at another angle of corporate performance which is beyond accounting information. It is also noted that the element of accounting information in the financial statements provides little information to stakeholders in terms of workplace culture, quality, brand, reputation, safety, strategies, know-how and other pertinent non-financial information. For some reasons, ESG information is very important for the management. According to Galbreath (2013), ESG can be used to assess leadership capabilities in a corporation by assisting the management to focus on a wide range of non-financial information, particularly regarding environmental, social and governance aspects. It also helps managers to proactively understand significant changes in a corporation's overall plans and make necessary changes and amendments to align with the original plan.

The basic idea of ESG information is that it serves as a tenet for investors to assess their potential investment (Chen, 2019). ESG enable investors to make better decisions on every investment made by identifying risks that can minimize their problems. Investors prefer shortterm investments which are always associated with higher risks (Global Sustainable Investment Alliance, 2018). ESG also provides one important element to the intangible assets of corporations reflecting the value of the brand (Ramadhani, 2019). Ethical performance, responsible corporations, employees' safety, and welfare are all intangible assets of ESG.

Accordingly, disclosure of ESG is important to be explored especially on its impact on financial performance. This study investigated the impact of ESG disclosures on financial performance of public listed companies (PLCs) in Malaysia. Environmental disclosures are defined as a collection of definition containing targets, reasons, and statistical data such as amount emissions and assets spent for a certain accounting period towards the environmental impact of the corporations (ACCA, 2005). The environmental aspect may also include a company's energy use, waste, pollution, natural resource conservation, and treatment of animals. The two means of disclosures as stated by Tze, Tho, Goh, Thai, and Teh (2016) are mandatory and voluntary environmental disclosures. Environmental disclosures which were previously voluntary, is currently made mandatory 
by Bursa Malaysia as a listing rule. Even though the stage of environmental disclosures in Malaysia is still at its infancy, it is progressing due to pressure from stakeholders who demand corporations to be accountable to disclose and report environmental information to them (Amran \& Siti Nabiha, 2009; Elijido-Ten, 2007; Mokhtar, 2015).

Other than environmental disclosures, social disclosures are another form of a corporation's relationship with stakeholders, with regard to social policy issues, as well as to society at large. Ever since the increase of environmental and social disclosures, there is also a rise in research related to these fields. Researchers have consistently postulated that highly profitable corporations are those corporations which are more "socially" and "environmentally-sensitive" industries (Gray, Javad, Power, \& Sinclair, 2001). Therefore, disclosure studies need to consider both the environmental and social dimensions.

Governance, on the other hand, was not a mandatory or legal requirement until the reinforcement of corporate governance structure through the Sarbanes Oxley Act (SOX) 2002 in the United States and the Cadbury Committee study in the United Kingdom in 1992. As for public listed companies in Malaysia, the Revised Malaysian Code of Corporate Governance (MCCG) 2017 requires all PLCs in Malaysia to disclose their corporate governance information in their annual report. Board leadership and effectiveness are governed by Principle A, effective audit and risk management are under Principle B and the integrity of corporate reporting and meaningful relationship with stakeholders are stipulated under Principle C. All these three principles under the Revised MCCG 2017 help tighten the relationship between corporations and stakeholders.

This paper is organized as follows: Section 2 provides a review of literature and the theories underpinning the study, Section 3 discusses the methodology, Section 4 explains the research framework and hypotheses development, Section 5 discusses the results, and Section 6 concludes the paper. 


\section{LITERATURE REVIEW}

The literature discussing ESG is quite abundant More recently, Chen (2019) defineds ESG criteria as "a set of standards for a company's operations that socially conscious investors use to screen potential investments. Environmental criteria consider how a company performs as a steward of nature. Social criteria examine how it manages relationships with employees, suppliers, customers and the communities where it operates. Governance deals with a company's leadership, executive pay, audits, internal controls and shareholder rights."

Specifically, ESG criteria are created to capture additional dimensions of corporate performance, which are not reflected in the accounting financial data (Friede, Busch, \& Bassen, 2015). Stakeholders including investors noticed that financial information alone is not sufficient to ensure the sustainability of a business. The United Nations Environment Program Finance Incentive (UNEP FI) and the World Business Council for Sustainable Department 2010 believe that integrating ESG aspects are essential to gain key stakeholders' trusts (Keating \& Frumkin, 2003; Kotsantonis, Pinney, \& Serafeim, 2016). There are many standards, guidelines, rules and conventions that corporations are expected to comply for them to gain the essential trust of their key stakeholders (Stremikiene, Simanaviciene, \& Kovaliov, 2009). It is most likely that ESG disclosure is the most visible means for sustainability reporting.

ESG disclosure is part of discharging accountability to stakeholders. The three main dimensions of environment, social and governance in ESG measure the sustainability and societal impact of an investment by corporations. These three main dimensions help measure not only financial performance but also future performance of corporations. Past studies have shown that different corporations have different strategies to outfit for ESG disclosures, giving an impact towards financial performance (Friede, Busch, \& Bassen, 2015; Ruhaya, Razali, Said, \& Zainon, 2016; Kweh, Alrazi, Chan, Abdullah, \& Lee, 2017; Tze et al., 2016; Zhao, 2018). The results are inconclusive as they are mixed between positive and contradictory. Irrespective of the inconclusive results, studies have shown that good sustainability management is vital in increasing the efficiency of corporations in the long run (Bachoo, Tan, \& Wilson, 2013; Riyadh, Sukoharsono, \& Alfaiza, 2019). 
The Stakeholder Theory (ST) is always used to investigate the link between ESG and corporate financial performance. The Theory was developed in the 1960s and gained popularity in the 1980s. Freeman (1984) originally detailed the ST of organizational management and business ethics that addresses morals and values in managing an organization. Stakeholders group include both internal and external partners such as investors, creditors, environmentalists, and the government, assessing the performance of organizations by analyzing the disclosure of financial information in annual reports. After decades, there has been an increasing concern in business integrity and the ST has emerged as one of the most influential theories in governance issues.

Previous researchers (Duran \& Rodrigo, 2018; Hao, Moreira, \& Haq, 2017; Ismail \& Kemal, 2017; Atan et al., 2016; Tarmuji, Maelah \& Tarmuji, 2016) have used the ST to clarify environmental and social disclosure because it has the ability to deliver to the needs of stakeholders that require management's attention. Drawing on the ST as a basis, an earlier study by Ullman (1985) used it in corporate social responsibility by shifting the way the company puts attention to its social issues. In this regard, stakeholders have increasingly pushed firms to disclose information concerning ESG aspects in their operations. The efforts of corporations concerning ESG might increase the relationships with stakeholders through non-financial disclosures. These relationships influence stakeholders to support investment for the corporations in the future (Majoch, Hoepner, \& Hebb, 2017; Zhao, 2018). The ST also indicates that the management should have a good relationship with their stakeholders to be a success (Tarmuji et al., 2016).

\section{METHODOLOGY}

\section{Population, Sample and Data Collection}

The population of this study was drawn from the total number of public listed companies in the Datastream database by Thomson Reuters 2019. A total of 952 companies listed consists of the Main market and Access, Certainty, Efficiency (ACE) market. The sample of the study was initially intended based on the census method where data was gathered on every member of the population. However, at the time this research was conducted, 
a number of companies dropped out of the database, leaving 114 companies with complete ESG information as a sample for this study. The companies were from multiple sectors such as utilities, transportation and logistics, telecommunication and media, property, plantation, industrial products, healthcare, energy, customer products and construction. The banking industry was excluded from the sample due to the unique characteristic of its regulations by the Banking and Financial Institutions Act (BAFIA) 1989 and different reporting requirements. Therefore, the final sample of 114 public listed companies which represented $11.9 \%$ of the population was appropriate for this study. The highest category was consumer products (24 companies) and the least was healthcare (3 companies). The sample was then categorized based on the firm size using total assets (Ln). Annual reports for the year 2019 of the sample companies were chosen as secondary data information for data collection purposes. The extent of disclosures made through annual reports can be considered for this study as there were many previous studies which used annual reports as a channel for information (Ahmad, Hassan, \& Mohammad, 2003; Kweh et al., 2017; Haniffa \& Cooke, 2005; Mohd Ghazali, 2007; Atan et al., 2016).

\section{ESG Score Index}

Most studies on ESG information disclosure of PLCs in Malaysia used the ESG score index. The effects of the three E, S and G scores are separately measured as E-environmental score (ESCORE), S-social score (SSCORE) and G-governance score (GSCORE). There were 57 dimensions of ESCORE, 60 dimensions of SSCORE and 48 dimensions of GSCORE, summing up to 165 dimensions altogether for ESGSCORE. In assessing the content of ESG, this study modified the ESG score based on previous studies by Atan et al. (2016) and Tarmuji et al. (2016). Major key considerations of environmental disclosure d efficient resource management and pollution prevention, reduction in carbon emissions and climate impact as well as environmental reporting/disclosure. Social disclosure, involved three main considerations of (i) workforce: diversity, health and safety, labour management, human rights, (ii) product integrity: safety, product quality, emerging technology issues and, (iii) engagement in community philanthropy. Governance score particularly needs disclosures on executive compensation, board accountability, shareholders' rights and reporting and disclosure. All these key considerations have the common benefit of aligning 
shareholders' interest with management hierarchy, consequently reducing reputational risks. We computed the score independently for each annual report of the PLCs.

\section{RESEARCH FRAMEWORK AND HYPOTHESES DEVELOPMENT}

The development of a research framework in this study was based on the anticipated relationships among the environmental, social and governance disclosure with financial performance, controlling the size of the firms. The framework was developed based on the ST hypothesis where three hypotheses were formed. The ST can provide an adequate research framework as a foundation for this study. Figure 1 depicts the relationship among the variables in the research framework.

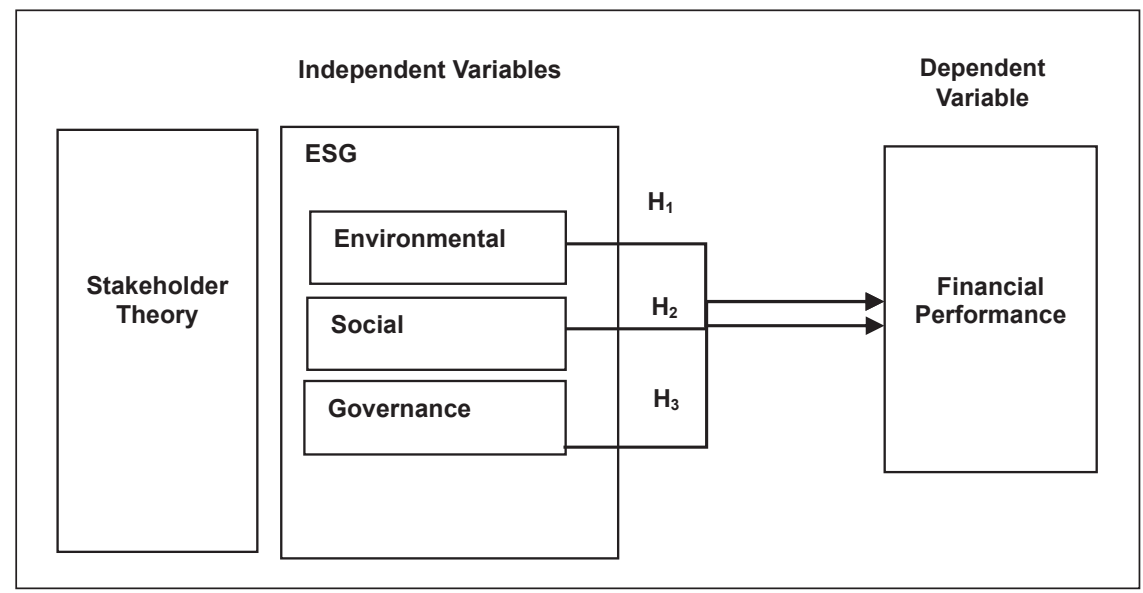

Figure 1: Research Framework

\section{ESG Disclosure}

In this study, we analyzed the effect of the $\mathrm{E}, \mathrm{S}$, and $\mathrm{G}$ scores towards financial performance seperately. The use of ESG disclosure indices was found in many disclosure studies (Elijido-Ten, 2007; Mohd Ghazali, 2007; Haniffa \& Cooke, 2002; Atan et al., 2016; Tarmuji et al., 2016) on the basis that it can accommodate the measurement needed for this study. ESG disclosure index of 165 items were computed for each company $j$ 
$(j=1,2, \ldots 114)$. The ESG disclosure score was then calculated where the score $I_{j}$ for each set of annual returns was as follows:

$\begin{aligned} \text { ESG Disclosure, ESGSCORE } & =\frac{\text { Number of items disclosed }}{\text { Total number of items (165) }} \\ & =\frac{\sum_{i=1}^{n} X_{i j}}{165} \times 100\end{aligned}$

where $\mathrm{n}=$ total number of items, $\mathrm{X}_{i j}=1$ if $i^{\text {th }}$ item is disclosed and otherwise.

\section{Financial Performance}

Past studies proved that financial performance plays an important role in attracting stakeholders' decisions to invest in a particular company. Financial performance also reflects economic performance. By disclosing the ESG mandatory requirements such as reducing air pollution and waste disposals, economic benefits can be brought into the firm (Tarmuji et al., 2016). Rationally, practicing ESG management practices, can affect the firm's performance and achievement of an organization. There are a lot of financial performance measures used, inter alia, Tobin's Q (Abu Bakar \& Ameer, 2011; Shakir, 2008), return on assets (Amran, Ooi, Nejati, Zulkafli, \& Lim, 2012; Elijido-Ten, 2007; Esa \& Mohd Ghazali, 2012), net profit margin (Abd. Rahman et al., 2009; Ahmad et al., 2003; Mohd Ghazali, 2007) in ESG disclosure studies. For this reason, this study tested the effect of ESG with the firm's performance, captured by the weighted average cost of capital (WACC), in line with Shakir (2008). WACC signify the return that stakeholders should expect which represents the investor's opportunity cost when they invest in a company. Various measures of financial performance used by previous studies showed the fact that financial performance is multidimensional (Kweh et al., 2017). The establishment of the relationship between ESG disclosures and financial performance, using multiple measures as proxies, however, need to be established as different measures could produce different outputs. 


\section{Relationship between Environmental Disclosures and Financial Performance}

There is a multitude of studies in the literature concerning the relationship between environmental disclosures and financial performance. Due to its abundance, the findings are mixed as there are distinct samples, measurements and methods used in the studies. Amran et al. (2012) found a positive and significant impact of environmental disclosure in 100 PLCs (35 members of sustainability networks; 65 conveniently selected from several industries). The influence of the environment on a firm's financial performance from previous research showed that there are studies using ESG as the dependent variable and some using ESG as the independent variable. In both relationships, environmental disclosures are due to the demand from stakeholders. Ultimate companies with good financial performance show that the companies enjoy continuous support from their stakeholders. On the other hand, there are also negative results of the relationship between the environmental disclosures and financial performance (Abdul Rahman, Yusoff, \& Wan Mohamed, 2009; Elijido-Ten, 2007). The connection of fiduciary relationships between stakeholders and the companies stimulated the interest for this study. Therefore, we hypothesized that:

H1: Environmental disclosure is positively associated with financial performance.

\section{Relationship between Social Disclosures and Financial Performance}

Pattern (1991, pp. 297-298) stated that "social disclosure is a means of addressing the exposure companies' face with regard to the social environment', and that 'the social legitimacy of business is monitored through the public-policy arena rather than the marketplace and, as such, the extent of social disclosure should be more closely related to the public pressure variables than the profitability measures."

From the above, Pattern (1991) pointed out that social disclosures refer to a company's voluntary contribution to sustainable development which goes beyond numbers and legal requirements. Social disclosure is one of the primary variables which mostly covers issues related to employees' relations 
which include health and welfare as well as training and development which include training in social responsibility (Qiu, Shaukat, \& Tharyan, 2016). Taking into consideration the importance of social disclosures, many related studies have been conducted in associating social disclosures and social responsibilities with financial performance. Many studies reveal that there is a positive association between social disclosures and performance (Amran, Ling, \& Sofri, 2007; Esa \& Mohd Ghazali, 2012; Hanifa \& Cooke, 2005) except for Barnett and Salomon (2012). Given the strong support of the positive relationship, we hypothesized that:

H2: Social disclosure is positively associated with financial performance.

\section{Relationship between Governance Disclosures and Financial Performance}

The literature on the relationship between governance disclosures and financial performance is quite embracing (Arora \& Sharma, 2016; Chen, 2019; Heaney, 2009) and furthermore, most of the findings were consistent where board size is positively significant with corporate performance. Governance dimensions include executive compensation, board accountability, shareholders' rights, reporting and disclosure aligning with the stakeholders' needs and expectations for information. Despite positive and significant relationship, the results of the study from Atan et al. (2016), showed that there is no significant relationship between individual and aggregate factors of ESG and firm performance, measured by the return on equity (ROE). Similarly, the study by Heaney (2009) based on 161 PLCs found that the governance factors such as board size and board independence were insignificant to the book to market ratio as the firms' performance. Accordingly, we hypothesized:

H3: Governance disclosure is positively associated with financial performance.

\section{Control Variable}

There are several measurements used as a representative of the controlling variables. It is possible that the independent variables used in one study could be the controlling variable in another study. One of the most 
common control variable is the size of the firm measured by total assets in the disclosure studies. Total assets are the investments held by the firm expecting to generate future economic benefits. Generating future economic benefits include generating cash flows, reducing expenses or improving sales. Firm size (FSIZE) measured by natural logarithm of total assets was included in this study, as a controlling variable. Often, larger size brings higher economy of scale to the firm (Taliento, Favino, \& Netti, 2019).

\section{RESULTS}

The main objective of this study was to investigate the impact of ESG disclosures on financial performance measured by the WACC of PLCs in Malaysia. Consequently, three sub-objectives in support of the main objective of (i) to investigate the relationship between environmental disclosure with financial performance; (ii) to examine the association between social disclosure with financial performance; and (iii) to examine the relationship between governance disclosure with financial performance. This section discusses data analysis that was performed and then presents the results. Data were first cleaned up and tested for normality using the Kolmogorov-Smirnov (K-S). Multicollinearity checks were performed to ensure that the variables used in this study are not highly correlated with one another. Descriptive analyses on the dependent, independent and control variables prepared us to conduct regression analysis. Tests of normality conducted showed that the distribution of scores of the variables did not deviated from the normal distribution. The skewness for the environmental score was -0.28 and kurtosis of -1.52 . The skewness for the social score was -1.12 and kurtosis of -1.29 . The skewness for the governance score was- 0.82 and kurtosis of -0.86 . Lastly, the skewness for WACC was also within the range (1.97). As the samples in this study were more than 30 (Pallant, 2011) the normality assumption should not cause problems, indeed the distribution of scores are normal if the value of skewness and kurtosis is between -2 and +2 (Tabachnick \& Fidell, 2007).

\section{Pearson's Correlation and Variance Inflation Factor}

Multicollinearity checks of Pearson's Correlation and Tolerance and Variance Inflation Factor (VIF) to test the correlation between two or more 
variables, whether they are highly correlated, were performed showing the following results. Table 1 shows the Pearson's Correlation of the variables in a one-tailed and two-tailed setting.

Table 1: Pearson Correlation of the Variables

\begin{tabular}{|c|c|c|c|c|c|c|}
\hline & Variables & WACC & ESCORE & SSCORE & GSCORE & FSIZE \\
\hline 1. & WACC & 1 & & & & \\
\hline 2. & ESCORE & $.188^{*}$ & 1 & & & \\
\hline 3. & SSCORE & $.152^{* *}$ & $.578^{* *}$ & 1 & & \\
\hline 4. & GSCORE & .221 & .059 & $.216^{*}$ & 1 & \\
\hline 5. & FSIZE & $.532^{\star *}$ & -.101 & 0.75 & -.073 & 1 \\
\hline
\end{tabular}

The results in Table 1 shows significant positive correlations between the ESG disclosure and some explanatory variables. SSCORE was significantly and positively related to financial performance, WACC $(\mathrm{r}=$ .152). This meant that financial performance of the firm increased when the firm disclosed more information on social information. There was a significantly positive correlation between SSCORE and ESCORE $(r=$ .578). From these three dimensions of ESG, PLCs in Malaysia are most likely to disclose more social disclosure information because they believe that social information can improve and enhance their performance. Other correlations were mainly positive and above 0.50 , except for the negative correlation which existed between the size of the company (FSIZE) and environmental disclosure $(\mathrm{r}=-.101)$. However, as expected, there was a significant positive correlation between FSIZE and WACC $(\mathrm{r}=.532, \mathrm{p}<0.01)$. Overall, it can be clearly seen that correlations of ESCORE, SSCORE and GSCORE were all positive with WACC. The Pearson's correlation results also showed the absence of multicollinearity since the maximum value of untabulated VIF was not more than 10 (Hair, Black, Babin, \& Anderson, 2010). The results of VIF for ESCORE (4.700); SSCORE (3.250) and GSCORE (3.531) suggest that there were no multicollinearity problems for multivariate analysis.

\section{Descriptive Statistics}

The descriptive statistics of this study is shown in Table 2 presenting the mean, minimum and maximum statistics of the items disclosed for each dimension in ESG. 
Table 2: Descriptive Statistics

\begin{tabular}{lcccc} 
Disclosure & $\begin{array}{c}\text { Number of Items } \\
\text { Disclosed }\end{array}$ & Mean & Minimum & Maximum \\
\hline ESCORE & $\mathbf{5 7}$ & 39.43 & 26 & 48 \\
SSCORE & $\mathbf{6 0}$ & 46.54 & 49 & 52 \\
GSCORE & $\mathbf{4 8}$ & 41.75 & 31 & 43 \\
Total Score & $\mathbf{1 6 5}$ & 127.72 & & \\
\hline
\end{tabular}

Note: total score $=165$ items, $\mathrm{n}=114 \mathrm{PLCs}$, mean= number of items disclosed/165

Based on Table 2, the mean score for environmental disclosure (ESCORE) is 39.43 with a minimum of 26 and a maximum score of 48 . The highest mean score goes to social disclosure (SSCORE) for 46.54, indicating that social disclosure is the highest-disclosed dimension in ESG disclosures. While ESCORE is the least-disclosed dimension, governance disclosure (GSCORE) is in the middle of environmental and social disclosures. Overall, ESG disclosures for PLCs in Malaysia is considered to be moderate with the mean average between 39.43 to 46.54 .

\section{Regression Analysis}

Table 3 reports the outcomes of the regression analysis. The model was significant at the 0.01 significance level. The result shows that social disclosure (SSCORE) has a positive relationship with financial performance (WACC) and the coefficient is significant (.0187). While previous studies that focus on ESG found positive results between environmental disclosures and performance (Abdul Rahman et al., 2009; Elijido-Ten, 2007), this study found otherwise, i.e. negative results between ESCORE and performance. The coefficient of social (SSCORE) was positive and significant and this finding is similar with Amran, Ling, and Sofri (2007); Esa and Mohd Ghazali (2012) as well as Haniffa and Cooke (2005). This result suggests that social disclosure has profound implications on financial performance. In addition, the coefficient value of size of the firm (FSIZE) was positive and significant, showing that larger firms are more likely to create correspondingly larger social disclosures. Higher social disclosure makes the firm a more appealing investment to the socially responsible investor, given adjusted $\mathrm{R}^{2} .488$ that shows only $48.8 \%$ of the variables are explained in the model. The results of this study are in support of $\mathrm{H}^{2}$. 
Table 3: Regression Results (Dependent Variable: WACC)

\begin{tabular}{|c|c|c|}
\hline \multicolumn{3}{|c|}{ DV: Weighted Average Cost of Capital (WACC) } \\
\hline \multirow[b]{2}{*}{ Predictors } & \multicolumn{2}{|c|}{ Regression } \\
\hline & Coefficient & Prob. \\
\hline Constant & .0232 & .0156 \\
\hline ESCORE & -.0008 & .0072 \\
\hline SSCORE & $.0187^{* *}$ & .0020 \\
\hline GSCORE & .0153 & .0040 \\
\hline FSIZE & $.0243^{* *}$ & .0331 \\
\hline $\mathrm{R}^{2}$ & \multicolumn{2}{|c|}{.108} \\
\hline Adjusted $\mathrm{R}^{2}$ & \multicolumn{2}{|c|}{.488} \\
\hline
\end{tabular}

Note: $\mathrm{n}=114,{ }^{*} \mathrm{p}<0.05 ;{ }^{* *} \mathrm{p}<.01$

\section{CONCLUSION}

This study examined the impact of ESG on the financial performance of PLCs in Malaysia based on the 2019 data from Datastream as provided by Thomson Reuters. Empirical evidence provided significant findings and a positive effect of social disclosure and size of the firm on financial performance. The study found that the focus of disclosure is on social disclosures, followed by governance and environmental disclosures. The regression analysis showed a positive relationship between social and governance disclosures with the financial performance, but the negative effect between environmental disclosures and financial performance. Accountability of the firms was towards the trusts given by the stakeholders, for the firms to have a drive and positive engagement in disclosing ESG information to meet stakeholders' expectations. This study highlighted that social disclosure of information provided by the firms reward them as socially responsible firms and consequently improve their financial performance. The results from this study can further assist stakeholders in selecting which firms they wish to invest in.

Adherence to international accountability standards, sustainability reporting, enhancing disclosures and transparency are efforts to uphold the relationships between firms and stakeholders. PLCs can demonstrate what 
they achieved through disclosure of ESG information to their stakeholders. In the same vein, PLCs that credibly engage with ESG have improved their performance. Empirical research found that firms with high ESG disclosures had higher stock returns and performed better in terms of profitability, growth, sales than their peers (Lin et al., 2016) or competitors.

This study has important implications for academics and practitioners. Although there are several previous studies that focused on ESG disclosures, this study contributes in such a way that ESG disclosures in certain areas fill the gaps in the literature. For academic implications, whereas most previous studies used single or combined ESG factor, this study concentrated on the inter dimension of environmental, social and governance separately. This study used the relative measures of WACC as a measure of financial performance representing measures of economic performance based on the context. Despite using content analysis as the methodology in measuring and analyzing data, this study used the Thomson Reuters Datastream which is still new and limited. For practitioners, tightening rules and regulations from a voluntary approach to a mandatory approach could better increase accountability and reporting to stakeholders.

The findings of this empirical study should be seen with potential limitations that might be viewed as a potential opportunity to open new areas for future research. A limitation of this study is that empirical findings were limited by the sample and the availability of full information on ESG. The results of this study may also be affected by the ESG disclosure indices. Robustness checks of the results could be performed for introducing inter-effects of the dependent and independent variables. Interchanging the dependent to independent, and vice versa, inter alia, may bring in different and conclusive results. The results of this study may serve as a starting point for future research by considering stakeholders' background and interests and their relationship with both combined ESG and interdimensional of ESG analyzed by each disclosure. This could probably improve and strengthen Principle C of the Revised MCCG 2017 - the integrity of corporate reporting and meaningful relationship with stakeholders. 


\section{ACKNOWLEDGEMENTS}

This article is a joint work of the six authors. The authors wish to acknowledge Universiti Teknologi MARA Cawangan Johor for supporting this research project. The authors also would like to thank the anonymous reviewers for their insightful comments and suggestions.

\section{REFERENCES}

Abdul Rahman, S. A., Yusoff, R., \& Wan Mohamed, W. N. (2009). Environmental disclosure and financial performance: An empirical study of Malaysia, Thailand and Singapore. Social and Environmental Accountability Journal, 29(2), 46-58.

Abu Bakar, A. S., \& Ameer, R. (2011). Readability of corporate social responsibility communication in Malaysia. Corporate Social Responsibility and Environmental Management, 18(1), 50-60.

Ahmad, Z., Hassan, S., \& Mohammad, J. (2003). Determinants of environmental reporting in Malaysia. International Journal of Business Studies, 11(1), 69-90.

Amran, A., \& Siti Nabiha, A. K. (2009). Corporate social reporting in Malaysia: A case of mimicking the West or succumbing to local pressure. Social Responsibility Journal, 5(3), 358-375.

Amran, A., Ling, L. L., \& Sofri, Y. (2007). A study of corporate philanthropic traits among major Malaysian corporations. Social Responsibility Journal, 3(4), 21-30.

Amran, A., Ooi, S. K., Nejati, M., Zulkafli, A. H., \& Lim, B. A. (2012). Relationship of firm attributes, ownership structure and business network on climate change efforts: Evidence from Malaysia. International Journal of Sustainable Development \& World Ecology, 19(5), 406-414.

Ariya Consulting. (2019). Environmental, social and governance - ESG criteria. Retrieved from https://www.ariyagroup.asia/2019/05/10/envi ronmental-social-and-governance-esg-criteria/ 
Arora,A., \& Sharma, C. (2016). Corporate governance and firm performance in developing countries: Evidence from India. Corporate Governance: International Journal of Business in Society, 16(2), 420-436.

Association of Chartered Certified Accountants (ACCA). (2005). The state of corporate environmental and social reporting in Singapore. Singapore: ACCA.

Atan, R., Razali, F. A., Said, J., \& Zainon, S. (2016). Environmental, social and governance (ESG) disclosures and its effect on firm's performance: A comparative study. International Journal of Economics and Management, 10(S2), 355-375.

Bachoo, K., Tan, R., \& Wilson, M. (2013). Firm value and the quality of sustainability reporting in Australia. Australian Accounting Review, 23(1), 67-87.

Barnett, M., \& Salomon, R. (2012). Does it pay to be "really" good? Addressing the shape of the relationship between social and financial performance. Strategic Management Journal, 33(11), 1304-1320.

Chen, J. (2019). Environmental, social and governance (ESG) criteria. Retrieved December, 12, 2019 from https:/www.investopedia.com/ terms/e/environmental-social-and-governance-esg-criteria.asp.

Duran, I. J., \& Rodrigo, P. (2018). Why do firms in emerging markets report? A stakeholder theory approach to study the determinants of non-financial disclosure in Latin America. Sustainability, 10(9), 3111.

Elijido-Ten, E. (2007). Applying stakeholder theory to analyze corporate environmental performance: Evidence from Australian listed companies. Asian Review of Accounting, 15(2), 164-184.

Esa, E., \& Mohd Ghazali, N. A. (2012). Corporate social responsibility and corporate governance in Malaysian government-linked companies. Corporate Governance: The International Journal of Business in Society, 12(3), 292-305. 
Freeman, R. E. (1984). Strategic management: A stakeholder approach. Boston: Pitman.

Friede, G., Busch, T., Bassen, A. (2015). ESG and financial performance: Aggregated evidence from more than 2000 empirical studies. Journal of Sustainable Finance \& Investment, 5(4), 210-233.

Galbreath, J. (2013). ESG in focus: The Australian evidence. Journal of Business Ethics, 118(3), 529-541.

Global Sustainable Investment Alliance. (2018). 2018 Global Sustainable Investment Review. Retrieved from http://www.gsi-alliance.org/

Gray, R., Javad, M., Power, M. D., \& Sinclair, C. D. (2001). Social and environmental disclosure and corporate characteristics: A research note and extension. Journal of Business Finance \& Accounting, 28(3-4), 327-356.

Hair, J. F., Black, W. C., Babin, B. J., \& Anderson, R. E. (2010). Multivariate data analysis ( $7^{\text {th }}$ ed.). New Jersey: Pearson Prentice Hall.

Haniffa, R. M., \& Cooke, T. E. (2002). Culture, corporate governance and disclosure in Malaysia corporations. Abacus, 38(3), 317-349.

Haniffa, R. M., \& Cooke, T. E. (2005). The impact of culture and governance on corporate social reporting. Journal of Accounting and Public Policy, 24(5), 391-430.

Hao, Y., Moreira, A. G., \& Haq, S. H. I. U. (2017). Corporate governance in Cape Verdean banks: A theoretical review. Management, 7(6), 194-201.

Harte, G., \& Owen, D. (1992). Environmental disclosure in the annual reports of British Companies: A research note. Accounting, Auditing and Accountability Journal, 4(3), 51-61.

Heaney, R. (2009). The size and composition of corporate boards in Hong Kong, Malaysia and Singapore. Applied Financial Economics, 19(13), 1029-1041. 
Ismail, S., \& Kemal, C. (2017). The impact of environmental, social and governance dimensions of corporate social responsibility on economic performance: Australian evidence. Procedia Computer Science, 120, 797-804.

Keating, E. K., \& Frumkin, P. (2003). Reengineering nonprofit financial accountability: Toward a more reliable foundation for regulation. Public Administration Review, 63(1), 3-15.

Kotsantonis, S., Pinney, C., \& Serafeim, G. (2016). ESG integration in investment management: Myths and realities. Journal of Applied Corporate Finance, 28(2), 9-16.

Kweh, Q. L., Alrazi, B., Chan, Y. C., Abdullah, W. M. T. W., \& Lee, R. M. A. (2017). Environmental, social and governance and the efficiency of government-linked companies in Malaysia. Institutions and Economies, 9(2), 55-74.

Majoch, A. A. A., Hoepner, A. G. F., \& Hebb, T. (2017). Sources of stakeholder salience in the responsible investment movement: Why do investors sign the principles for responsible investment?. Journal of Business Ethics, 140, 723-741.

Mohd Ghazali, N. A. (2007). Ownership structure and corporate social responsibility disclosure: Some Malaysian evidence. Corporate Governance, The International Journal of Business in Society, 7(3), 251-266.

Mokhtar, N. (2015). The extent of environmental management accounting (EMA) implementation and environmental reporting (ER) practices: Evidence from Malaysian public listed companies (Doctoral dissertation, University of Malaya).

Pallant, J. (2011). SPSS survival manual: A step by step guide to data analysis using the SPSS program ( $4^{\text {th }}$ ed.). Allen \& Unwin: Berkshire.

Pattern, D. M. (1991). Exposure, legitimacy and social disclosure. Journal of Accounting and Public Policy, 10(4), 297-308. 
Qiu, Y., Shaukat, A., \& Tharyan, R. (2016). Environmental and social disclosures: Link with corporate financial performance. The British Accounting Review, 48, 102-116.

Ramadhani, R. (2019). Understanding environment, social and governance (ESG) factors as path toward ASEAN sustainable finance. Asia-Pacific Management and Business Application, 7(3), 147-162.

Riyadh, H. A., Sukoharsono, E. G., \& Alfaiza, S. A. (2019). The impact of corporate social responsibility disclosure and board characteristics on corporate performance. Cogent Business \& Management, 6(1), 1647917.

Shakir, R. (2008). Board size, executive directors and property firm performance in Malaysia. Pacific Rim Property Research Journal, 14(1), 66-80.

Stremikiene, D., Simanaviciene, Z., \& Kovaliov, R. (2009). Corporate social responsibility for implementation of sustainable energy development in Baltic States. Renewable and Sustainable Energy Reviews, 13(4), 813-824.

Tabachnick, B. G., \& Fidell, L. S. (2007). Using multivariate statistics (5th ed.). New York: Allyn and Bacon.

Taliento, M., Favino, C., \& Netti, A. (2019). Impact of environmental, social, and governance information on economic performance: Evidence of a Corporate 'Sustainability Advantage' from Europe. Sustainability, $11,1738$.

Tarmuji, I., Maelah, R., \& Tarmuji, N. H. (2016). The impact of environmental, social and governance practices (ESG) on economic performance: Evidence from ESG score. International Journal of Trade, Economics and Finance, 7(3), 67-74.

Tze, S. O., Tho, H. S., Goh, H. H., Thai, S. B., \& Teh, B. H. (2016). The relationship between environmental disclosures and financial performance of the public listed companies in Malaysia. International Business Management Medwell Journal, 10(4), 461-467. 
Ullmann, A. A. (1985). Data in search of a theory: A critical examination of the relationships among social disclosure and of performance, social, economic performance US firms. Academy of Management Review, 10(3), 540-557.

Zhao, C., Guo. Y., Yuan, J., Wu, M., Li, D., Zhou, Y., \& Kang, J. (2018). ESG and corporate financial performance: Empirical evidence from China's listed power generation companies. Sustainability, 10, 2607. 